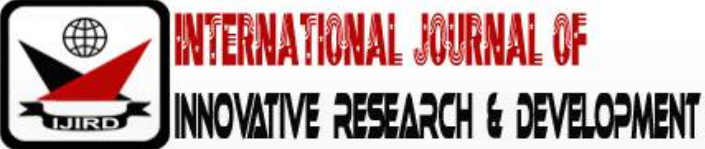

ISSN 2278 - 0211 (Online)

\section{Innovation of Guidance and Counseling Method by Assimilating Local Indigenous: Case Study of Dwijendra's Ethical-Spiritual Values Implementation}

\begin{tabular}{|c|}
\hline Dwi Umi Badriyah \\
Graduate Student, Department of Guidance and Counseling, \\
Semarang State University, Indonesia \\
Dr. DYP Sugiharto \\
Lecturer, Department of Guidance and Counseling, \\
Semarang State University, Indonesia \\
Dr. Rustono, M.Hum \\
Lecturer, Department of Guidance and Counseling \\
Semarang State University, Indonesia \\
Dr. Ida Bagus Yudha Triguna \\
Lecturer, Department of Hindu Religion Education, \\
Indonesian Hindu University, Indonesia
\end{tabular}

\begin{abstract}
:
This study describes the Dwijendra's ethical values and implementation method to change the student character and behavior. Dwijendra's ethical-spiritual values was construct based on "Mokshartam Jagadhita ya ca iti Dharma" and combined with local wisdoms. The implementation process of Dwijendra's ethical-spiritual values includes: pawintenan saraswati, (2) dharma wacana, (3) dharma sadhana, (4) evaluation and reflection. It can give an insight and contribution to construct a model of guidance and counseling in school.
\end{abstract}

Keywords: Counseling, ethical, guidance, indigenous, spiritual

\section{Introduction}

Indigenous Counseling is a counseling method that affords the examination, interpretation, and analysis based on cultural substantial aspects (Kim, Yang \& Hwang, 2010). The indigenous counseling approach is talked on the cultural context, therefore sometime, it also called indigenous psychology (Shweder, 2000). There are six fundamental assumptions of indigenous psychology:1) It emphasize on the understanding with ecologist, cultural, and historical context as the source, 2) the cultural is not a study on the exotic people at far place, 3) The recognizing of various perspective on social culture could not divided on all groups, 4) it is not assert the usage of certain methods, 5) There is inherent benefits from one specific perspective compare to others, 6) the main purpose is to find the universal principals and facts (Kim and Berry, 1993).The indigenous source is containing valuable material about the essence of human behavior, interpersonal interaction, social and human personality (Kim, Yang and Hwang, 2010).

Indigenous and cultural physiology (Kim, Yang \& Hwang, 2010) and Multicultural Counseling (Baruth and Manning, 2003; Hanna, Bemak, Chung, and Ying, 1999) are the example of counseling method that assimilate the local indigenous values. The comprehension of multicultural counseling is similar with having a competence on indigenous counseling, because every culture has an indigenous value. Indigenous counseling will construct people perspective toward human being and universe. Indigenous counseling is also showing their comprehension to self, person, live goals, and values of living (Nager, 2000; McLeod, 2003).

Guidance and counseling based on Dwijendra's ethical-spiritual values is an innovation of local wisdom, culture and indigeneity of Bali. Bali is known as a Hinduism island, in which this affecting many aspects of people life (McDaniel, 2017). According to Balinese, maintaining the spiritual and ethical balance is manifested in the act of dharma and adharma concepting catur purusartha. These ideals of Balinese life are specifically taught by Danghyang Dwijendra, a spiritual person. Danghyang Dwijendra is a spiritual person, pedanda agung, yogi, as well as purohito. Dwijendra teaches ethicalspiritual values. Those ethical-spiritual values are effective and efficient in students' character building and behavior change from maladaptive into adaptive in line with the ideals of Balinese life (Sugriwa, 1993).

Guidance and counseling in Dwijendra high school applied Dwijendra's ethical- spiritual values to help students build their character and change their behavior from maladaptive into prami patena, that is, mastering science and 
technology as well as excelling in moral, ethic, manner, and devotion to God as in line with the school mission. In counseling, there is an approach focusing on cognitive restructuring distortion due to physical or psychological traumatic experiences. This approach was implemented since it was not easy for some students to take advices and change their behavior.

\section{Rationale for the Study}

Develop a new innovation on counseling by assimilating with local genius from indigenous culture is important. Implementation of Dwijendra's ethical-spiritual values is one of the examples of counseling innovation, because ethicalspiritual values content on Dwijendra theory can be absorbed on the counseling process and implemented on the student character building and behavioral change. This perspective needs to be developed considering that various theories of counseling are rooted from western assessment (Pedersen, 2002; McLeod, 2010; Kim, Yang and Hwang, 2010). Danghyang Dwijendra is the main figure in which his behavior inspires the emerging and developing the Dwijendra High School. The teachings and live values of Danghyang Dwijendra, e.g. divinity, spirituality, moral, ethical, aesthetic, leadership etc., become tradition that internalized on the education, teaching and guidance process in this school. Reconstruction and restructure of student character and behavior on the guidance and counseling by integrating Dwijendra's ethical- spiritual values from local genius and have an indigenous content are very appropriate to apply on the guidance and counseling process with Bali culture and Hinduism religious as a Background. The questions that would like to answer in this research as follows:

- How is Dwijendra's ethical-spiritual values could be described on guidance and counseling?

- How the implementation of Dwijendra's ethical-spiritual values for reconstructing and restructuring students' character and changing their behavior?

\section{Method}

\subsection{Participants}

Participants of this research are all teachers, counselor, staff and student of Dwijendra High School, Bali, Indonesia. For student participant, its limited to the student that participated on yogasana and art activity, in which they are experiencing the process of behavioral characterization, establishment, and transformation accordance with the Balinese tradition, culture and aspiration. Yogasana is an activity related to body and spiritual processing that exemplified by Danghyang Dwijendra. The main purpose of yogasana is resting our body, focusing our mind and spiritual to Sanghyang Widi (God of Hindu people) for expressing our thankfulness, admiration, praise and prayer. Art activities are divided into two groups, pure arts and literature.

\subsection{Experimental Design}

This study was conducted using phenomenology research method (Dilthey, 1977; Solomon and Higgins, 2002). The instruments that used in this study are informants (interview), events or activities, various images, documents and archives, and field notes. The model of this research is described on figure 1.

\subsection{Data Analysis}

Process of data analysis was done using quadric hermeneutic (Alvesson and Skolberg, 2000). For document source data, interpretation and confirmation process was used to minimize the subjectivity by the authors. Interpretation are divided into two steps, interpretation by school counselor and continued with the interpretation by authors. Related to data collected from interview, data was process based on theory of the fusion of horizons (Gadamer, 2006) or horizontalizing (Creswel and Pothl, 1998). Basically, data analysis on this research can be simplified into three activities, data reduction, data display and conclusion drawing (Miles and Haberman, 1994).

\section{Result and Discussion}

\subsection{Dwijendra's Ethical-Spiritual Values Related to Guidance and Counseling}

The concept of Dwijendra's ethical-spiritual values that can be absorbed and assimilated into guidance and counseling related to character building are divided into 13 values (Table 1). Individual character build from its values is constructed on the ideals life of Balinese, called Moksatham Jagadhita Ya Ca Iti Dharma. Two major points, ethical and spiritual, are explained in that ideal's life (Figure 2). Spiritual value shows the balance relation between human and God. This relationship must be balanced and harmonized with the life attitude. For Hindu people in Bali, maintaining the stability and balance between spiritual and ethical relation is not only in order to achieving temporal prosperity or happiness, but also toward afterlife happiness or they called it moksa.

In related with behavioral transformation, Dwijendra's ethical-spiritual values theory can be assimilated into guidance and counseling and divided into four value. Those values are yogasana, upakara, art, and dharmayatra. First, Yogasana is a behavioral transformation technique focusing on relaxation and meditation. This technique is similar with systematical desensitization on behavioral counseling. The essence of this technique is relieving negative behavior and enclose the opposite response. This process also called unconditional positive regard that resulting warmth, acceptance and nonjudgmental attitude (Corey, 2009; Flanagan and Flanagan, 2004; Gillon, 2007). Second, Upakara is an equipment to make a ceremony become alive and perfect. Upakara need to be train, because it is included in social religion education. The training to prepare upakara is including skill, expertise, persistence, and ability to interpret, therefore it is an effective 
technique for behavioral transformation. This technique also could be found in behavioral counseling as social modeling and live peer model. Third, art is a technique that related to symbolic model or mediation process. Fourth, Dharmayatra is a holy journey with purpose to increase the individual purity through prayer asking God (Sanghyang Widhi) mercy for our mistake and sin, and also to strengthening faith to God. Dharmayatra is also a ritual that applying strong relationship between healthiness with spirituality and religion. Adaptive new mindset and behavior are resulted from this process.

Explanation related with assimilation of Dwijendra's ethical-spiritual values to guidance and counseling method give an insight that behavioral transformation needs a harmony and balance between spiritual and ethical aspects. The content of Moksatham Jagadhita Ya Ca Iti Dharma is filled with harmony and balance concept. The purpose of behavioral transformation by those two aspects is to make the student that changed possess the peace of mind so they can control their mind better, calming their emotion, and gentle when they talk. Finally, their behavioral transformation will make other people feel calmness and peacefulness.

Guidance and counseling applied in Dwijendra High School are filled with Dwijendra's ethical-spiritual values. The relation between its values with guidance and counseling theories and previous studies are described in table 2 . Education process in Dwijendra is not only make the students possess a cognitive knowledge but also a devotion to God. Interaction between students and teachers are happen simultaneously which means teachers are not only teaching, but at the same time also involve in their teaching process. It is also happened in the process of guidance and counseling, in order to achieving idealism of Moksartham jagadhita ya ca iti dharma (Winaya, 2015)

\subsection{Reconstruction and Restructuration of Dwijendra's Ethical-Spiritual Value to Students}

The implementation of Dwijendra's ethical and spiritual values is done through reconstruction and restructuration process. The form of implementation is described in figure 3. Reconstruction process are based on the theory in which the process involves interpretation of the psychoanalysis data to describe individual development that already happen together with the signification possess by those individuals (Caplin, 1997). The responsibility of reconstruction person is to see all viewpoints (events, phenomena, history, mind conception) so that all can be built again in accordance with actual situation and avoiding the over subjectivity. This viewpoint places the individual reconstruction process in Dwijendra high school to the direction of character building based on Moksartham jagadhita ya ca iti dharma. Implementation is also done through restructuration process. Restructuration is known as a rearrangement process, so the structure or order become better. On the guidance and counseling, there is an approaching theory in which it is focusing on deviate cognitive restructuration that causing disadvantages on the individual physiology and physic. The theory is called Cognitive Behavioral Therapy (CBT). CBT is directed to a modification the function of mind, feel and behavior with focusing on brain to analyze, making decision, asking, acting and redecide. Whereas, related to behavioral aspect, it is directed to build good relation between problems situation and the habit to react to the problems. CBT invite person to learn how change their behavior by calmness their mind and body so they can feel better, think clearer and help them to make a clear decision (Cully and Teten, 2008; Teater, 2013). One example of behavioral restructuration process in Dwijendra High School is yogasana in which the CBT is manifested.

\section{Conclusion}

In conclusion, Dwijendra's ethical-spiritual values could be applied to guidance and counseling in relation to the students' character building and relation to behavior change. All of these values that can be applied to guidance and counseling are drawn into moksartham jagadhita ya ca iti dharma construct that creating students with prami patena (knowledgeable and devoted to God) personality. The moksartham jagadhitaya ca iti dharma construct is in accordance with the mindset, action and life ideals of the Balinese.

\section{Conflict of interest}

The authors declared that there is no conflict of interest in this paper.

\section{References}

i. Alvesson, M., \& Skolberg, K. (2000). Reflexive methodology: New vistas for qualitative research. Sage Publications, Inc.

ii. Baruth, L. G., \& Manning, M. L. (2003). Multicultural counseling and psychotherapy: A Lifespan perspective. Merrill / Prentice Hall.

iii. Chaplin, J. P. (1997). Dictionary of psychology. Dell.

iv. Corey, G. (2009). Theory and practice of counseling and psychotherapy, Eight Ed. Thomson Higher Education.

v. Creswell, J. W., \& Poth, C. N. (1998). Qualitative inquiry and research design: Choosing among five approach. Sage Publications, Inc.

vi. Cully, J. A., \& Teten, A. L. (2008). A Therapist's guide to brief cognitive behavioral therapy. Department of Veterans Affair. South Central Illness Research, Education, and Clinical Center (MIRECC).

vii. Dilthey, W. (1977). Descriptive psychology and historical understanding. Nijhoff. Flanagan, J. S., \& Flanagan, R. S. (2004). Counseling and psychotherapy theories in context and practice: skill, strategies, and techniques. John Wiley \& Sons, Inc.

viii. Gadamer, HG. (2006). Truth and method (continuum impacts). Bloomsbury Academic. Gillon, E. (2007). PersonCentered counseling psychology: An Introduction. Sage Publications.

ix. Hanna, F. J., Bemak, F., \& Chung, R. CY. (1999). Toward a new paradigm for multicultural counseling. Journal of Counseling \& Development, 7(2), 125-134. https://doi.org/10.1002/j.1556-6676.1999.tb02432.x. 
X. Kim, U., \& Berry, J. W. (1993). Cross-cultural research and methodology series, Vol. 17. Indigenous psychologies: Research and experience in cultural context. Sage Publications, Inc.

xi. Kim, U., Yang, KS., \& Hwang, KS. (2006). Indigenous and cultural psychology: Understanding people in context. Springer.

xii. McDaniel, J. (2017). Religious change and experimentation in Indonesia Hinduism. International Journal of Dhama Studies, 5(20), 1-14. https://doi.org/10.1186/s40613- 017-0056-x

xiii. McLeod, J. (2003). An Introduction to counselling. Open University Press.

xiv. Miles, M. B., \& Hubeman, A. M. (1994). Qualitatif data analysis: An expanded sourcebook (2nd ed.). Sage Publications, Inc.

xv. Nager, N., \& Shapiro, K. (2000). Revisiting a progressive pedagogy. The Developmental interaction approaches. SUNY series, early childhood education: inquiries and insights. State University of New York Press.

xvi. Pedersen, P. B., Draguns J. G., Lonner, W. J., \& Trimble, E. (2002). Counseling across cultures, fifth edition. Sage Publication, Inc.

xvii. Shweder, R. (2000). The Psychology of practice and the practice of the three psychologies. Asian Journal of Social Psychology, 3, 207-222. https://doi.org/10.1111/1467-839X.00065

xviii. Solomon, C. R., \& Higgins, M. K. (1996). A Short history of p0hilosophy. Oxford University Press.

xix. Sugriwa, IG. B. S. (1993). Dwijendra Tattwa. Upada Sastra.

xx. Teater, B. (2013). Cognitive behavioral therapy. In Davies M. (Ed.), The Blackwell companion to social work (pp 1-8). Willey-Blackwell.

xxi. Winaya, P. K. K. (2015). Beberapa bagian penting dalam ajaran agama hindu. Swasta Nulus 